\title{
COMMENT ON D. E. PARKER, 'EFFECTS OF CHANGING EXPOSURE OF THERMOMETERS AT LAND STATIONS’
}

\author{
WAR WICK S. HUGHES \\ Tasman Institute, 457 Elizabeth St., Melbourne, Victoria 3000, Australia \\ Received 6 May 1994 \\ Accepted I6 September 1994
}

\begin{abstract}
This short note reviews the Minutes of two Intercolonial Meteorological Conferences, held at Melbourne, Australia in 1881 and 1888, where the transcripts refer to the use of the Stevenson screen. Additional historical and modern material is reviewed demonstrating the use of the Stevenson screen in late nineteenth century Australia and Fiji. Some possible implications for the climate change debate in Australia are considered.
\end{abstract}

KEY WORDS: Australia; climate change; Fiji; intercolonial meteorological conferences; Stevenson screen

\section{INTRODUCTION}

In his comprehensive paper surveying world-wide historical changes in thermometer exposure, Parker (1994), in paragraph 3.2 dealing with Australia, states that a motion at the 1888 Intercolonial Meteorological Conference in Melbourne, to install Stevenson screens at all Australian stations, was not passed (Ellery, 1888). Although there can be no doubt that the motion did not pass, it should be pointed out that in the minutes of the three Intercolonial Meteorological Conferences (Russell, 1879; Ellery, 1881, 1888) there are several references to the use of the Stevenson screen by the participants, the Observatory Heads of the various colonies which then made up Australia and New Zealand. Formal standardization was certainly not vitally important to most of the delegates but a motion aimed at greater uniformity may have stood more chance of success had it not been for personality clashes between certain delegates (Ellery, 1888).

\section{THE INTERCOLONIAL METEOROLOGICAL CONFERENCES}

Minutes of the proceedings of the three Colonial Meteorological Conferences, 1879, 1881, and 1888, show clearly that the main business was the telegraphic transmission of observations between the colonies and the standardization of these data to be shared. We are fortunate that some record of the discussion of the standardization of thermometer exposure has survived, because it was clearly not a major issue in the minds of the Observatory Heads, who had interests in, for example, astronomy, geophysics, and geodesy.

Minutes of the 1879 Conference show only a brief mention on p. 8 that shade temperature and thermometer sheds, among several other subjects for experimentation, will be referred to each member of the conference for future consideration and report.

Minutes of the 1881 Conference in Melbourne (Ellery, 1881) reveal comments on the issue by the Adelaide (South Australia), Sydney (New South Wales), and Melbourne (Victoria) delegates, starting at para. 65(d). Mr Todd describes some comparisons made at Adelaide in para. 67 and in paras 68-69, Mr Russell describes experiments made at Sydney. At para. 77, Mr Ellery talks about experiments to determine true shade temperature at Melbourne, and in para. 79, the statement, 'In a Stevenson's stand made for one of the country stations', is strong evidence that it was in fact quite routine that a Stevenson stand was to be sent

CCC 0899-8418/95/020231-04

(C) 1995 by the Royal Meteorological Society 
to a country station. Mr Ellery goes on to describe a rather elaborate thermometer shed for use at the Observatory in Melbourne. In para. 185 the question of uniformity of exposure is raised again but there seems to have been little energy left for the subject.

Minutes of proceedings of the third Conference (Ellery, 1888) record additional members present from Western Australia, Queensland, and Tasmania. The general tone is set at the top of p. 8, where Mr Russell (Sydney) says the issue was fully discussed at the last conference. Mr Ellery (Melbourne), the Chairperson, keeps the subject going by saying that, 'he advocated, for country stations, the Stevenson stand; every observatory had different stands, but he had kept the Stevenson stand going....

The enthusiastic Mr Wragge (Queensland), moved a motion that the Royal Meteorological Society approved Stevenson screen be slightly enlarged and used throughout Australasia. Mr Todd describes experiments at Adelaide which show, 'the ... Stevenson screen thermometers are nearer than ... other modes to the temperature shown by a swinging thermometer'. Mr Wragge chips in to talk about the Torrens Observatory (near Adelaide) established by him, which he claims to be the first established in Australia to be run on Royal Meteorological Society principles. One imagines that these comments would go over like the proverbial 'lead balloon' and that this was not the way for Mr Wragge to obtain the co-operation of other delegates.

Mr Russell rejoins to say that 'they had all used the Stevenson stand and made their own adaptations. They had failed to agree and it was not important anyway because thermometers were unreliable'. Then followed several comments to the general effect that they need not slavishly follow the Royal Meteorological Society. Sir James Hector said that 'for 25 years passed only Stevenson screens had been used in New Zealand, with slight modifications'. Mr Todd said 'he was going to adopt the Stevenson screen for his out-stations'. Captain Shortt, from Tasmania, said 'he used the same one as Mr Ellery,...' and despite the Chairperson trying to cajole them into a position of greater uniformity in the matter, Mr Wragge could not get a seconder for his motion.

It is significant that despite all of this haggling and fussy display of independence, nobody is on record as proposing to keep using the old style stands, with thermometers exposed to radiation from the ground.

In addition to the quotes in the minutes above, Charles Todd (1878), shows that in the late 1860s he was familiar with this innovation of $\mathrm{Mr}$ Thomas Stevenson of Edinburgh. He describes a large octagonal thermometer shed with a louvred roof and wide open latticed walls, which with commendable colonial independence of mind, he thought was superior to the Stevenson screen in the Adelaide climate. He attributes the design of his shed to "the late Mr Smalley, at the Sydney Observatory'. This is evidence of an early move away from open stand exposure at Sydney too.

Charles Todd and Mr. Smalley were much up-to-date with events in the mother country, as far as one can judge from a reading of the meteorological literature from the late $1860 \mathrm{~s}$.

\section{REVIEW OF MODERN REFERENCES}

Burrows and Staples (1991), survey trends in maximum temperatures in South Australia and state that the Stevenson screen was used at all of their country stations, including seven records commenced in the 1890 s. This supports the statement of Charles Todd in Ellery (1888), that 'he was going to adopt the Stevenson screen for his out-stations'.

In 1992 Alex Kariko, Bureau of Meteorology Research Centre, Melbourne, in a talk to a Bureau of Meteorology seminar, related how he had found a photograph, dated ca. 1890, in the Darwin library, showing a Stevenson Screen in the Darwin Post Office back yard (see Figure 1). This further supports the statement above by Charles Todd.

Minues of the 1888 Conference reveal the constant involvement of Mr Clement Wragge, the Queensland delegate and the friction between him and other delegates. Home and Livingstone (1994), summarize $\mathrm{Mr}$ Wragge's impact on meteorology in a number of the colonies, in their detailed survey of the evolution of nineteenth and early twentieth century meteorology in Australia, including events surrounding federation. 


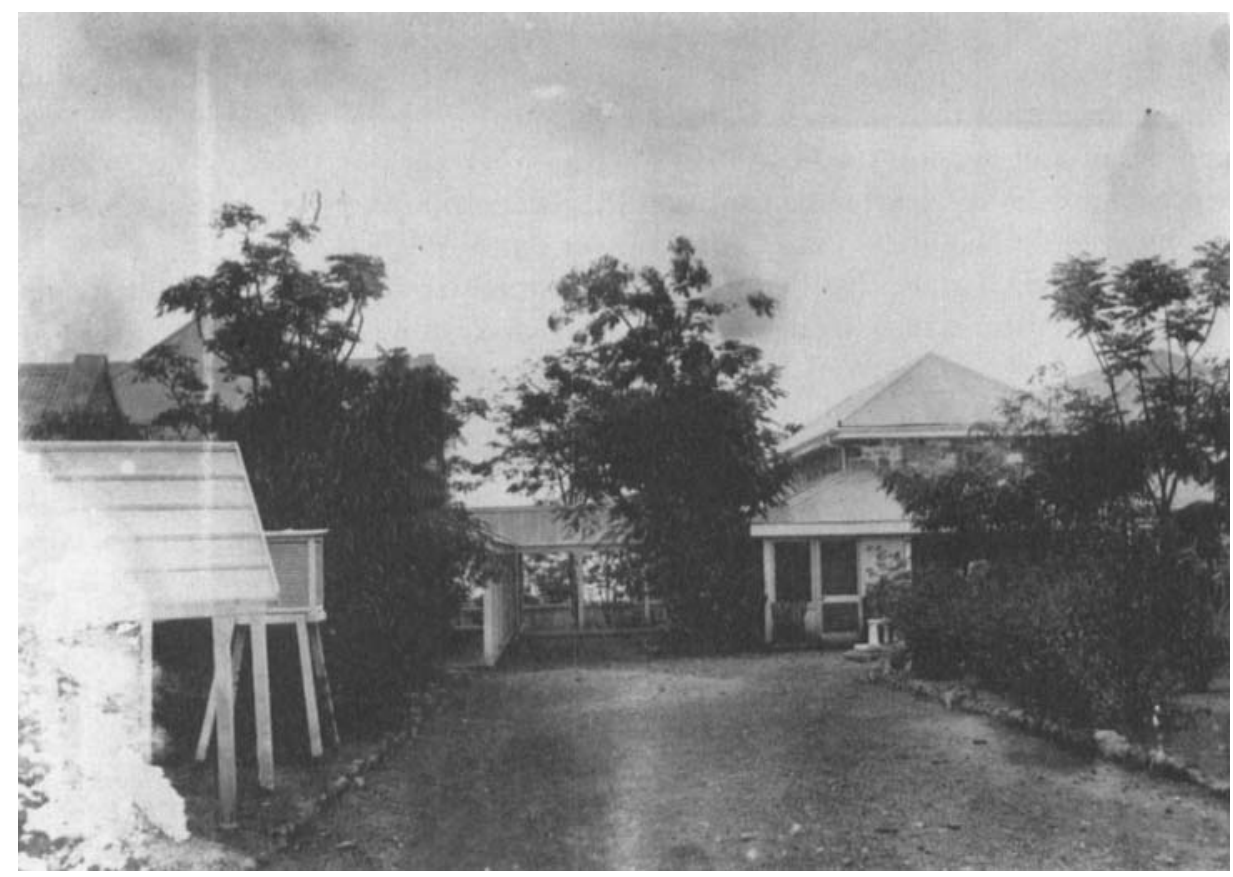

Figure 1. Stevenson Screen outside Darwin Post Office, 1890. Photograph 1/28 in the Tracey Collection, from the Northern Australian Collection of the State Library of the Northern Territory

\section{COLONY BY COLONY SUMMARY}

With respect to paragraph 3.2 in Parker (1994), on Australia, the above evidence shows that South Australia (which included the Northern Territory at that time), was using the Stevenson screen at out-stations from about 1890 .

In the case of Victoria, Ellery's quotes from the 1881 and 1888 minutes are mutually supportive and indicate the use of the Stevenson screen at high order country stations from the early $1880 \mathrm{~s}$.

The statement from Captain Shortt of Tasmania in Ellery (1888), about using the same one as Mr. Ellery, further confirms Australia as a region where the Stevenson screen was used before the twentieth centry.

In the caser of New South Wales, the evidence is not as strong but the statement by H. C. Russell in the minutes of the 1888 Conference that, 'they had all used the Stevenson stand and made their own adaptations', might suggest that the situation was much the same as in surrounding colonies.

\section{FIJI}

Holmes (1881) describes observations at a plantation in Fiji, where thermometers were exposed in a 'louvre boarded box'. In para. 157, pp. 20 of Ellery (1881), there is a quote from Hector that Holmes, 'an able observer, had been furnished by the Govt. of New Zealand with a complete set of instruments'. Thus, in view of the use of the Stevenson screen in New Zealand since 1870 (Parker, 1994, para. 3.19), it seems likely that Holmes' 'louvre boarded box' may have been a Stevenson Screen. 


\section{IMPLICATIONS FOR CLIMATE CHANGE DEBATE}

There is a view in Australian meteorological circles, expreased by Pittock (1993): 'The most notable problem in the data is the change from the Glaisher to the Stevenson screen early this century'. This statement was made in the context of a discussion on Australian long-term temperature records and the justification for a negative correction pre-1900. Clearly this view that the Stevenson screen was introduced after 1900 is not consistent with much of the historical evidence that is set out in this note.

Torok and Nicholls (1993) state that, 'A discontinuity more complex and difficult to pinpoint is the introduction of the Stevenson screen, from the 1880 s in some regions to early this century in others'. No regions are specified but the findings of Parker (1994), regarding open stands, would suggest that any discontinuity on an overall mean annual basis may be very slight. The opposing effects on daytime maxima (open stands too warm) and night-time minima (open stands too cold) may, however, be somewhat greater. This could be more important in view of the need to explain recent tendencies to reduced diurnal temperature range (Karl et al., 1993).

\section{CONCLUSIONS}

The balance of evidence from several sources points to the introduction of the Stevenson screen in Australia and Fiji in the late nineteenth century. This conclusion, together with Parker's (1994) findings regarding open stands weighs against the need for a significant pre- 1900 overall negative correction to many Australia temperature records.

\section{ACKNOWLEDGEMENTS}

Professor R. W. Home, of the Department of History and Philosopy of Science, The University of Melbourne, has read my drafts and offered his views, which are appreciated. Thanks are also due to the Burea of Meteorology staff who reviewed my 1992 draft.

\section{REFERENCES}

Burrows, K. R. and Staples, M. J. 1991. Trends in South Australian Maximum Temperature Records, A Joint Research Project of the Bureau of Meteorology and the South Australian Department of Environment and Planning, Burea of Meteorology, Adelaide, $42 \mathrm{pp}$.

Donaldson, J. 1888. Account of the Operations of the Weather Bureau and List of Stations, Meteorological Branch, Queensland Post and Telegraph Department, General Post Office, Brisbane, 6 pp.

Ellery, R. L. J. 1881. Minutes of Proceedings of the Intercolonial Meteorological Conference held at Melbourne on the 2/st, 22nd, 25th, 26th and 27th, April, 1881, Presented to both Houses of Parliament by His Excellency's Command, By Authority, R. S. Brain, Acting Government Printer, Melbourne, $26 \mathrm{pp}$.

Ellery, R. L. J. 1888. Minutes of Proceedings of the Intercolonial Meteorological Conference held at Melbourne, 11-15 September, 1888, Presented to both Houses of Parliament by His Excellency's Command, By Authority, R. S. Brain, Government Printer, Melbourne, $16 \mathrm{pp}$.

Holmes, R. L. 1881. 'The climate of Fiji: results of meteorological observations taken at Delanasau, Bua, Vanua Levu, Fiji, 1871-88', Q.J.R. Meteorol. Soc., 7, p. 222-243.

Home, R. W. and Livingstone, K. T. 1994. 'Science and technology in the story of Australian Federation: the case of meteorology, 1876-1908', Aust. J. Politics His., in press.

Kariko, A. 1992. Bureau of Meteorology Seminar.

Karl, T. R., Jones, P. D., Knight, R. W., Kukla, G., Plummer, N., Razuvayev, V., Gallo, K. P., Lindseay, J., Charlson, R. J. and Peterson, T. C. 1993. 'A new perspective on global warming: asymmetric trends of daily maximum and minimum temperature', Bull. Am. Meteorol. Soc., 74, 1007-1023.

Parker, D. E. 1994. 'Effects of changing exposure of thermometers at land stations', Int. J. Climatol, 14, 1-31.

Pittock, A. B. 1993. 'A reply to John Daly's arguments', University of Western Sydney, Hawkesbury, Occasional Papers in Biological Sciences No. $1, p p .53-57$.

Russell, H. C. 1879. Minutes of Proceedings of the Intercolonial Meteorological Conference held at Sydney, 11th, 13th and 14th, November, 1879. Presented to both Houses of Parliament by His Excellency's Command, By Authority, Thomas Richards, Government Printer.

Todd, C. 1878, Meteorological Observations made at the Adelaide Observatory during the Year 1876, E. Spiller, Acting Government Printer.

Torok, S. and Nicholls, N. 1993, 'Inhomogeneities in the Australian temperature record', Reprint No. 8, Symposium on Meteorological Observations and Instrumentation, 17-22nd January 1993, Anaheim, California. 